\title{
Inleiding op het thema Conceptual Framework
}

Ralph ter Hoeven

Het Conceptual Framework van de International Accounting Standards Board (IASB) is een onderdeel van het niet-verplichte deel van de International Financial Reporting Standards (IFRS). Dat betekent dat bedrijven die op basis van IFRS rapporteren niet als zodanig aan de bepalingen van het CF hoeven te voldoen. In die zin heeft het Conceptual Framework dezelfde status als de implementation guidance en de basis for conclusions die de publicatie van een IFRS begeleiden. Het CF is ook geen onderdeel van het Europese goedkeuringsproces van IFRS.

Desalniettemin wijden wij een themanummer aan het Conceptual Framework en in het bijzonder aan de wijzigingsvoorstellen (ED/2015/4) die op 28 mei 2015 door de IASB zijn gepubliceerd. De vraag is waarom de redactie daartoe heeft besloten als het $\mathrm{CF}$ toch geen formeel onderdeel is van IFRS. Dan gaat het dus over de relevantie van het Conceptual Framework voor de externe verslaggeving. Deze relevantie kent twee aspecten waarvan er een ligt op het gebied van de verslaggevingspraktijk en de ander ligt op het gebied van (toekomstige) regelgeving.

In de eerste plaats is het CF wel degelijk van belang in situaties dat er geen specifieke regel binnen IFRS bestaat voor de verwerking van een bepaalde gebeurtenis of transactie. Ondernemingen en accountants zullen in deze situaties het CF kunnen gebruiken om te beoordelen of een verwerkingsgrondslag in lijn is met de uitgangspunten van het CF. Ook in bedrijfsovernamesituaties dient het overnemende bedrijf de overgenomen activa en verplichtingen te identificeren indien en voorzover deze voldoen aan de definities van activa en verplichtingen zoals opgenomen in het $\mathrm{CF}^{1}$.

In de tweede plaats staat het CF aan de basis van toekomstige regelgeving. De IASB zal bij de ontwikkeling van toekomstige standaarden deze altijd ijken aan de bepalingen van het CF. Dit geldt bijvoorbeeld voor de toekomstige standaard over voorzieningen. Het zou merkwaardig zijn als in deze (overigens nog te ontwikkelen) standaard uitgegaan wordt van een verplichtingenbegrip dat afwijkt van de keuzes die gemaakt zijn in het CF. De keuzes die gemaakt zijn in het CF zullen derhalve doorwerken in de ontwikkeling van toekomstige standaarden en daarmee van de toekomstige verslaggeving.

Deze redenen waaraan de relevantie van het CF kan worden ontleend verklaren mijns inziens ook waarom het $\mathrm{CF}$ zo vaak werd genoemd in de zogenoemde agendaconsultaties van de IASB. Dit zijn consultatierondes van de IASB waarin aan de achterban wordt gevraagd aan welke standaarden of projecten de IASB in de toekomst prioriteit zou moeten geven. In de consultatie die in 2011 is uitgevoerd werd door de meeste respondenten de herziening van het $\mathrm{CF}$ als prioriteit aangemerkt.

Dit herzieningsproces is inmiddels weer een stap verder door de publicatie van de Exposure Draft Conceptual Framework For Financial Reporting (ED/2015/4; hierna: ED) die ik hiervoor al heb aangehaald. De IASB achtte de herziening van het bestaande CF noodzakelijk om de volgende redenen.

1. het huidige CF dekt bepaalde gebieden niet af; bijvoorbeeld op het gebied van verslaggeving over ondernemingsprestaties;

2. de bepalingen zijn soms onduidelijk; en

3. sommige onderdelen zijn verouderd.

In dit themanummer gaan we na of de herziening van het $\mathrm{CF}$, vanuit verschillende perspectieven bezien, als een succes beschouwd kan worden. Een viertal artikelen zullen op deze materie nader ingaan.

In het eerste artikel van mijn hand worden de hoofdlijnen van de ED besproken. Aandacht wordt besteed aan de opbouw van de ED alsmede aan die onderdelen die een behoorlijke verandering hebben ondergaan ten opzichte van het huidige CF. Specifiek wordt ingegaan op definities van elementen, het voorzichtigheidsbeginsel, balansopnamecriteria en waarderingsgrondslagen. Ook komt het onderscheid tussen de winst-en-verliesrekening en other comprehensive income (OCI) aan de orde. Geconcludeerd wordt dat de IASB de ED vooral heeft aangepakt om keuzes te rechtvaardigen die hij in een eerder stadium bij de ontwikkeling van specifieke standaarden heeft ge- 
maakt. Vanuit dit gezichtspunt kan worden gesproken van een 'filling the gap'-exercitie.

In het tweede artikel gaat Hoogendoorn in op de relatie tussen de algemene beginselen zoals deze in Titel 9 en de EU Accounting Directive naar voren komen en het CF. Een onderwerp dat ook centraal stond in de in 1993 gehouden oratie van Hoogendoorn. Hoogendoorn acht het opvallend dat de algemene beginselen een zo beperkte plaats hebben in het CF. Hij concludeert dat de algemene beginselen nog steeds hun waarde hebben, maar dat het belangrijk is te beseffen dat voor sommige beginselen in de loop der tijd een wijziging is opgetreden in inhoud en/of mate van toepassing en dat de uitwerking kan verschillen tussen IFRS enerzijds en Titel 9 en RJ anderzijds.

In het derde artikel behandelt Backhuijs enkele aspecten van de in de ED opgenomen definities van activa, vreemd vermogen en het daaruit resulterende eigen vermogen van de onderneming. Hij stelt vast dat vooralsnog geen aandacht wordt besteed aan activa en vreemd vermogen uit hoofde van de relatie van de onderneming met de overheid op basis van wetgeving in plaats van marktconforme contracten. Ook constateert Backhuijs dat het onderscheid tussen eigen en vreemd vermogen van de onderneming vooralsnog onduidelijk blijft, omdat de IASB geen duidelijke keuze maakt tussen het proprietary concept en het entity concept. Deze concepten worden door de auteur nader besproken.

In het vierde en laatste artikel van dit themanummer constateert Brouwer dat de IASB in de ED vast blijft houden aan een balansbenadering waarbij baten en lasten worden afgeleid van de mutaties in balansposten.
Hij constateert dat er geen duidelijke definitie wordt gegeven van het begrip financiële prestatie en dat omschrijvingen hiervan niet bruikbaar zijn als basis voor de ontwikkeling van toekomstige standaarden. Verder merkt Brouwer op dat de IASB het gedeelte over financiële prestatie reduceert tot een presentatievraagstuk gericht op other comprehensive income en recycling. Relevante informatieverschaffing over prestaties vraagt echter volgens Brouwer om een meer prominente plaats in het CF en een minder binaire aanpak van de ontwikkeling van concepten die aan de basis staan van toekomstige standaarden.

Al met al leidt het beeld van de artikelen tot de constatering dat de IASB nogal wat kansen heeft laten liggen om het CF daadwerkelijk te verbeteren. Daarbij dient bedacht te worden dat de ED uiteraard een voorstel betreft; niet voor niets spreken we over een exposure draft. Laten we hopen dat alle binnengekomen commentaar (de termijn hiervoor liep af op 26 november 2015) die ongetwijfeld ook veel kritische elementen genoemd in dit themanummer zullen bevatten, de IASB zal aanzetten de nodige verbeteringen aan te brengen.
Prof. dr. R.L. ter Hoeven RA is partner op het vaktechnisch centrum van Deloitte Accountants en hoogleraar externe verslaggeving aan de Rijksuniversiteit Groningen.

\section{Noten}

Enkele uitzonderingen daargelaten; zie het volgend artikel in dit themanummer van mijn hand. 